\title{
Beta cell coupling and connexin expression change during the functional maturation of rat pancreatic islets
}

\author{
C. P. F. Carvalho • H. C. L. Barbosa • A. Britan • \\ J. C. R. Santos-Silva • A. C. Boschero • P. Meda • \\ C. B. Collares-Buzato
}

Received: 29 September 2009 / Accepted: 22 January 2010 /Published online: 2 April 2010

(C) Springer-Verlag 2010

\begin{abstract}
Aims/hypothesis Cell-cell coupling mediated by gap junctions formed from connexin $(\mathrm{CX})$ contributes to the control of insulin secretion in the endocrine pancreas. We investigated the cellular production and localisation of CX36 and CX43, and gap junction-mediated beta cell coupling in pancreatic islets from rats of different ages, displaying different degrees of maturation of insulin secretion.

Methods The presence and distribution of islet connexins were assessed by immunoblotting and immunofluorescence. The expression of connexin genes was evaluated by RT-PCR and quantitative real-time PCR. The ultrastructure of gap junctions and the function of connexin channels were assessed by freeze-fracture electron microscopy and tracer microinjection, respectively.

Results Young and adult beta cells, which respond to glucose, expressed significantly higher levels of $C x 36$ (also known as Gjd2) than fetal and newborn beta cells, which
\end{abstract}

Electronic supplementary material The online version of this article (doi:10.1007/s00125-010-1726-8) contains supplementary material,

which is available to authorised users.

C. P. F. Carvalho · J. C. R. Santos-Silva •

C. B. Collares-Buzato $(\square)$

Department of Histology and Embryology, Institute of Biology,

University of Campinas (UNICAMP),

Campinas, São Paulo CEP 13083-970, Brazil

e-mail: collares@unicamp.br

H. C. L. Barbosa $\cdot$ A. C. Boschero

Department of Physiology and Biophysics, Institute of Biology, University of Campinas,

Campinas, São Paulo, Brazil

A. Britan · P. Meda

Department of Cell Physiology and Metabolism, Medical School, University of Geneva,

Geneva, Switzerland respond poorly to the sugar. Accordingly, adult beta cells also showed a significantly higher membrane density of gap junctions and greater intercellular exchange of ethidium bromide than newborn beta cells. Cx43 (also known as Gjal) was not expressed by beta cells, but was located in various cell types at the periphery of fetal and newborn islets.

Conclusions/interpretation These findings show that the pattern of connexins, gap junction membrane density and coupling changes in islets during the functional maturation of beta cells.

Keywords Beta cells $\cdot$ Cell-cell coupling · Connexins . Gene expression · Development - Gap junction . Insulin secretion · Maturation · Pancreatic islet
Abbreviations
CX Connexin
LY Lucifer Yellow

\section{Introduction}

When compared with adult islets, fetal and neonatal islets from different species exhibit a reduced secretory response to glucose and other secretagogues [1-8]. The nature of this poor responsiveness is not fully understood, and has been variably attributed to many factors, including fuel metabolites, intracellular signals, hormones and other environmental conditions [1-3, 8-11].

Cell-cell contacts mediated by gap junctions are crucial for a proper secretory response of the endocrine pancreas. The synthesis and release of insulin are markedly altered after dispersion of beta cells in vitro, but rapidly recover 
after cell reaggregation, indicating that the secretory mechanism depends on intercellular interactions within the pancreatic islet $[12,13]$. Several in vivo and in vitro studies have demonstrated that insulin secretion stimulated by glucose and other secretagogues is associated with increased gap junction coupling of beta cells, whereas the pharmacological blockage of gap junction channels impairs the secretory function of beta cells [9, 14-16]. Thus, loss of connexin 36 after treatment of beta cell lines with antisense oligonucleotides or knocking out the gene (Cx36 [also known as Gjd2]) in mice resulted in loss of beta cell coupling, associated with a loss of synchronisation of intracellular calcium oscillations, as well as altered basal and glucose-stimulated insulin secretion [17-20]. Together, these findings point to the importance of gap junctionmediated cell coupling in beta cell physiology.

The role of gap junctions in the developmental maturation process of beta cell function has not been evaluated. In this work we investigated the expression and localisation of the gap junction-associated connexins CX36 and CX43 and the ultrastructural and functional aspects of the intercellular channels which connexins form in pancreatic islets of rats of different ages. Our findings reveal a close relationship between the degree of maturation of the insulin secretory machinery, notably insulin expression and glucose-induced insulin secretion, and CX36-dependent coupling in rat pancreatic islets.

\section{Methods}

Animals Fetuses (embryonic day 20) and neonatal (1-2 days old) male and female Wistar rats and young (21 days old) and adult male (3-4 months old) Wistar rats were obtained from the breeding colony of the University of Campinas (Campinas, Brazil) or from the University of Geneva (Geneva, Switzerland). The animals were used in accordance with the guidelines of the Institutional Committee for Ethics in Animal Experimentation of the University of Campinas and the University of Geneva.

Immunofluorescence The cellular locations of connexins, insulin, glucagon and vimentin were determined by immunofluorescence staining of sections of pancreas frozen in $n$-hexane with liquid nitrogen, and cryosectioned $(8 \mu \mathrm{m})$. For the detection of CX36, insulin, glucagon and vimentin, the sections were fixed with acetone at $-20^{\circ} \mathrm{C}$ for $3 \mathrm{~min}$. For CX43 detection, the sections were fixed with $2 \%$ paraformaldehyde (wt/vol. in PBS, $\mathrm{pH} 7.4$ ) for $8 \mathrm{~min}$ and permeabilised with $0.1 \%$ Triton X-100 (vol./vol. in $0.05 \mathrm{~mol} / 1$ Tris-buffered saline [TBS], pH7.4) for $5 \mathrm{~min}$. All sections were then incubated for $1 \mathrm{~h}$ with $5 \%$ dry skimmed milk (wt/vol. in TBS, pH7.4) and then with the primary antibodies under the conditions listed in Table 1 of the Electronic supplementary material (ESM). Following incubation with the corresponding fluorochrome-labelled secondary antibody (ESM Table 1), the sections were mounted with Vectashield (Vector Laboratories, Burlingame, CA, USA) and observed using a confocal laser-scanning microscope (MRC 1024 UV; Bio-Rad Laboratories, Hercules, CA, USA; or LSM 510 META; Zeiss, Hamburg, Germany). To compare the different animal groups, islets from fetal, neonatal, young and adult animals were analysed during the same session using identical confocal parameters. The specificity of the primary antibodies was tested by omitting them and by incubating the sections in 3\% dry skimmed milk (wt/vol. in TBS). These negative controls did not result in consistent labelling of islet cells (data not shown).

Islet isolation Islets were isolated by type $\mathrm{V}$ collagenase digestion (EC 3.4.24.3; Sigma) of fetal, neonatal, young and adult pancreas in Hanks' balanced salt solution and, after separation with Ficoll gradients or Histopaque 1077 (Sigma, St Louis, MO, USA), were collected under a dissecting microscope. To minimise contamination by exocrine tissue, fetal and newborn islets were cultured for $24 \mathrm{~h}$ in RPMI-1640 medium supplemented with 5\% fetal bovine serum (vol./vol.), $10 \mathrm{mmol} / 1$ glucose, $100 \mathrm{IU}$ penicillin $/ \mathrm{ml}$ and $100 \mu \mathrm{g}$ streptomycin $/ \mathrm{ml}$ at $37^{\circ} \mathrm{C}$ in a $5 \%$ $\mathrm{CO}_{2}$ /air atmosphere. Most experiments tested freshly isolated young and adult islets. However, for comparison with fetal and neonatal islets, some freeze-fracture and quantitative realtime PCR experiments also investigated adult islets after culture. No marked difference in terms of Cx36 expression and gap junction numbers was observed between freshly isolated and cultured adult islets (data not shown).

Insulin secretion Five to 15 overnight-cultured islets from fetal, neonatal, young and adult rats were placed in $1 \mathrm{ml}$ Eppendorf tubes and preincubated for $30 \mathrm{~min}$ at $37^{\circ} \mathrm{C}$ in $0.5 \mathrm{ml}$ bicarbonate-buffered Krebs solution containing $3 \mathrm{mg} / \mathrm{ml}$ bovine serum albumin/ml and equilibrated to $\mathrm{pH}$ 7.4 with a mixture of $95 \% \mathrm{O}_{2}$ and $5 \% \mathrm{CO}_{2}$ (BBKS) [9] supplemented with $5.6 \mathrm{mmol} / 1$ glucose. The islets were then incubated for $1 \mathrm{~h}$ at $37^{\circ} \mathrm{C}$ in $0.5 \mathrm{ml} \mathrm{BBKS}$ supplemented with either 2.8 or $16.7 \mathrm{mmol} / 1$ glucose. Aliquots of the supernatant fraction were stored at $-20^{\circ} \mathrm{C}$. Secreted insulin was determined by RIA and expressed as ng islet ${ }^{-1} \mathrm{~h}^{-1}$ [9].

Western blotting Pools of at least 1,000 islets isolated from each animal group were homogenised by sonication in an antiprotease cocktail [9]. The total protein content of the lysates was determined using a DC protein assay kit (BioRad). Aliquots $(70 \mu \mathrm{g})$ of each group were incubated for $1 \mathrm{~h}$ at $37^{\circ} \mathrm{C}$ with $30 \%$ of the total volume made with $5 \times$ 
concentrated Laemmli sample buffer [9]. The samples were then fractionated by electrophoresis in $10 \%$ polyacrylamide gels and the proteins were electrotransferred to nitrocellulose membranes (Bio-Rad). The membranes were stained with Ponceau S solution (Sigma) and immunoblotted only when showing comparable staining of corresponding bands. Selected membranes were blocked overnight at $4{ }^{\circ} \mathrm{C}$ with TBS containing $0.05 \%$ (vol./vol.) Tween 20 plus $5 \%$ (wt $/$ vol.) dry skimmed milk. They were then incubated with the primary antibodies followed by incubation with their respective specific secondary antibody conjugated with horseradish peroxidase (HRP) [9] under the conditions given in ESM Table 2. After washing the membranes, the membranes were revealed using an enhanced chemiluminescence kit (SuperSignal West Pico Chemiluminescent Substrate; Pierce, Rockford, IL, USA) and autoradiography film (Amersham, Cleveland, $\mathrm{OH}, \mathrm{USA}$ ). Band intensities were quantified by optical densitometry using Image software (Scion, Frederick, MD, USA). The densitometric values of connexin signals were expressed relative to those of all proteins stained with Ponceau S, which were taken as $100 \%$. The specificity of antibodies was confirmed in brain and heart homogenates, used as positive controls for CX36 and CX43, respectively. Liver tissue, which was used as a negative control, showed, as expected, no signal for CX36 and a relatively weak band for CX43 (data not shown).

$R T-P C R$ Pools of approximately 1,000 islets were lysed in $1 \mathrm{ml}$ Trizol solution (Invitrogen, Carlsbad, CA, USA), and total RNA was extracted as described by the manufacturer. RNA concentrations were determined by measuring the optical absorbance at $260 \mathrm{~nm}$. cDNA was synthesised from $3 \mu \mathrm{g}$ islet RNA in a volume of $20 \mu \mathrm{l}$, using the reverse transcriptase SuperScript II and random hexamer primers (Invitrogen, USA). The primer sets used in RT-PCR analysis are shown in ESM Table 3. The number of amplification cycles was defined for each gene after titration between 18 and 42 cycles, using RNA islet samples from all animal groups in a PCR Thermal Cycler 9600 (PerkinElmer Cetus, Waltham, MA, USA). In all cases, negative controls were provided by submitting a sample of water to amplification (data not shown). PCR products were separated on $2 \%$ ethidium bromide-agarose gels, and band intensities were determined by digital scanning (GelDoc 2000; Bio-Rad) followed by quantification using Scion Image software. The $C \times 43$ and $C \times 36$ transcript levels were normalised to those of ribosomal protein S29 (Rps29).

Quantitative PCR Pools of 200-400 isolated neonatal and adult islets were lysed in a guanidinium thiocyanate solution and total RNA was extracted using the RNAqueous-Micro kit (Ambion, Austin, TX, USA). mRNAs $(0.5 \mu \mathrm{g})$ were reverse-transcribed using ImProm-
2 Reverse transcription system (Promega, Madison, WI, USA). RNA integrity was checked using a 2100 Bioanalyzer (Agilent, Santa Clara, CA, USA), and quantitative PCR was performed with a $7900 \mathrm{H}$ Sequence Detection System (Applied Biosystems, Foster City, CA, USA). The primers are listed in EMS Table 4. Each transcript was evaluated in triplicate. Mean values were normalised to the mean geometric value of the housekeeping genes Rps29, Gapdh and Eeflal.

Freeze-fracture electron microscopy Isolated neonatal and adult islets were fixed for $60 \mathrm{~min}$ in $2.5 \%$ glutaraldehyde solution (vol./vol.) and processed for freeze-fracturing $[16,21]$ using a BAF 60 Freeze Etching System (Balzers High Vacuum, Balzers, Liechtenstein). Replicas were examined with a Philips CM10 electron microscope. To evaluate beta cells, we only considered membrane profiles located in the islet centre and surrounded by cytoplasm displaying secretory granules [21]. Gap junctions and tight junctions were identified by their characteristic appearance [16]. Membrane and junction areas were photographed and measured using UTHSCSA Image Tool software (http://ddsdx.uthscsa.edu/dig/itdesc.html, version 3.0).

Tracer microinjection Neonatal and adult islets were attached to Sylgard- (Dow Corning, Midland, MI, USA) and poly-L-lysine-coated dishes as previously described [22], transferred to the heated stage $\left(37^{\circ} \mathrm{C}\right)$ of a Universal Zeiss microscope and kept in Krebs Ringer bicarbonate HEPES buffer $(117 \mathrm{mmol} / \mathrm{l} \mathrm{NaCl}, 4.7 \mathrm{mmol} / \mathrm{l} \mathrm{KCl}$, $2.5 \mathrm{mmol} / 1 \mathrm{CaCl}_{2}, 1.2 \mathrm{mmol} / 1 \mathrm{MgSO}_{4}, 1.2 \mathrm{mmol} / 1 \mathrm{KH}_{2} \mathrm{PO}_{4}$, $5.0 \mathrm{mmol} / 1 \mathrm{NaHCO}_{3}, 10 \mathrm{mmol} / 1 \mathrm{HEPES}$ ), $0.5 \%$ (wt/vol.) BSA and $10 \mathrm{mmol} / 1$ glucose, $\mathrm{pH} 7.3-7.4$, after equilibration with $\mathrm{O}_{2} / \mathrm{CO}_{2}$ (95:5, vol./vol.). Individual cells located in the islet centre were impaled using glass microelectrodes filled with a $4 \%$ solution (wt/vol.) in $150 \mathrm{mmol} / 1 \mathrm{LiCl}(\mathrm{pH} 7.2)$ of either Lucifer Yellow (LY; mol. wt 457, two negative charges) or ethidium bromide (mol. wt 394, one positive charge; wt/vol.), without altering the islet shape. After cell penetration, the tracers were injected iontophoretically for $5 \mathrm{~min}$ by applying $0.1 \mathrm{nA}$ square pulses of $900 \mathrm{~ms}$ duration and $0.5 \mathrm{~Hz}$ frequency. Pulses were negative for injection of LY and positive for ethidium bromide. In all cases, the extent of diffusion was captured with an Axiocam camera (Carl Zeiss, Oberkochen, Germany) coupled to the fluorescence microscope. The extent of coupling was determined by measuring the area labelled by each tracer on digitised photographs of the intact islets, using Image Tool software. The islets were then fixed in $4 \%$ paraformaldehyde $(\mathrm{wt} / \mathrm{vol}$. in $0.1 \mathrm{~mol} / 1$ phosphate buffer). Some of them were embedded in Epon (EMS, Hatfield, PA, USA), serially sectioned $(1 \mu \mathrm{m})$ and processed for checking the location of the injection site [22]. 
Statistical analysis Results are expressed as mean \pm SEM. For comparison between groups, statistical significance was assessed using Student's $t$ test. For multiple comparisons, statistical significance was assessed by ANOVA followed by the Bonferroni test. The $\chi^{2}$ test was used to compare the coupling incidence in adult and neonatal islets. The significance level was set at $p<0.05$. Statistical analyses were performed using the GraphPad Prism Version 4.00 for Windows (GraphPad Software, La Jolla, CA, USA).

\section{Results}

Fetal, neonatal and young islets had a similar basal release of insulin in the presence of $2.8 \mathrm{mmol} / \mathrm{l}$ glucose $(0.3 \pm 0.1[n=$ 10], $0.1 \pm 0.02[n=22]$ and $0.2 \pm 0.05[n=10] \mathrm{ng}$ islet $^{-1} \mathrm{~h}^{-1}$ respectively), which was lower $(p<0.001)$ than that of adult islets $\left(1.1 \pm 0.2 \mathrm{ng}\right.$ islet $\left.^{-1} \mathrm{~h}^{-1}, n=24\right)$. When stimulated with $16.7 \mathrm{mmol} / \mathrm{l}$ glucose, fetal and neonatal islets did not significantly increase their insulin release $(0.5 \pm 0.5[n=10]$ and $0.3 \pm 0.1[n=24] \mathrm{ng}$ islet $^{-1} \mathrm{~h}^{-1}$, respectively), whereas young and adult islets increased it $(1.9 \pm 0.4[n=10]$ and $9.5 \pm 0.8[n=22] \mathrm{ng}$ islet $^{-1} \mathrm{~h}^{-1}$ respectively; $\left.p<0.001\right)$. As a result, the fold increase in insulin release was significantly greater in young and adult islets compared with fetal and neonatal islets (Fig. 1).

The beta cells of young and adult islets showed substantial punctate staining for CX36, which was much less evident in fetal and neonatal islets (Fig. 2). Blots confirmed that young and adult islets has higher levels of CX36 compared with fetal and neonatal islets (Fig. 2). A different pattern was observed for CX43. Thus, beta cells were not immunostained for this $\mathrm{CX}$, whereas the same

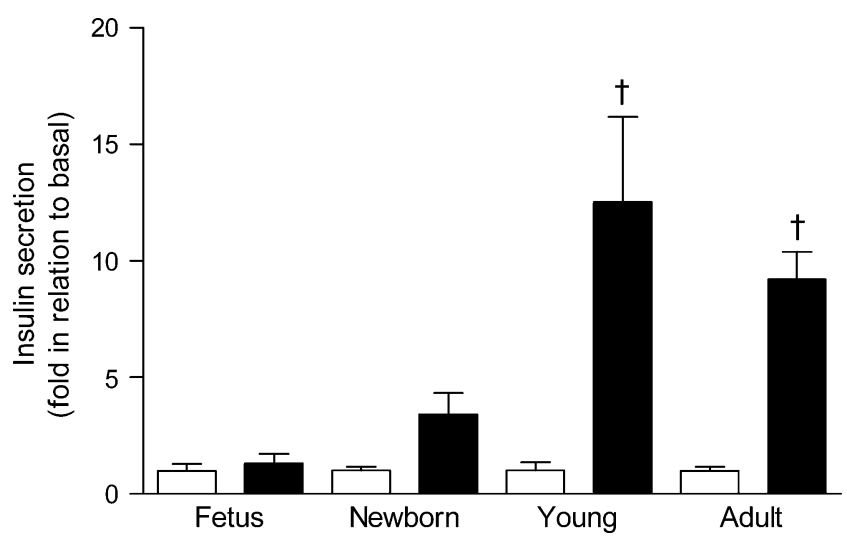

Fig. 1 Beta cells acquire glucose responsiveness after birth. Fetal and neonatal islets did not show significantly higher insulin secretion compared with the basal value observed in the presence of $2.8 \mathrm{mmol} / \mathrm{l}$ glucose (white bars) when exposed to $16.7 \mathrm{mmol} / \mathrm{l}$ glucose (black bars), whereas young and adult islets did. Values are mean + SEM fold increase over basal mean value (set to 1 ) of ten (fetal and young islets) to 24 experiments (neonatal and adult islets). ${ }^{\dagger} p<0.0001 \mathrm{vs}$ basal value $(2.8 \mathrm{mmol} / \mathrm{l}$ glucose $)$ within each group antibodies labelled vimentin-positive, duct and alpha cells at the periphery of fetal and neonatal islets (Fig. 3). Blots showed that whereas fetal and neonatal islets produced two forms of CX43, the form of lower electrophoretic mobility was preferentially detected in young and adult islets (Fig. 3).

RT-PCR showed that the levels of $C x 36$ mRNA increased $(p<0.001)$ with islet development, whereas those of $C x 43$ decreased $(p<0.05)$ in parallel (Fig. 4). Quantitative PCR confirmed the opposite changes in the two connexins, and further showed that the levels of Cx36 mRNA increased in parallel with those of mRNAs for both the insulin 1 and the insulin 2 gene $\left(C x 36\right.$ vs insulin $1, r^{2}=0.9232, p<0.0001$; $C x 36$ vs insulin $2, r^{2}=0.9748, p<0.0001$; Fig. 5).

Freeze-fracture electron microscopy showed that beta cells of both adult and neonatal islets displayed typical gap junctions, often associated with tight junctions (Fig. 6). However, the proportion of beta cell membranes showing gap junctions was higher $(p<0.0001)$ in adult than in neonatal islets, because of a 3.5 -fold increase in the numerical density of gap junctions (Table 1).

Microinjection of islets with either LY or ethidium bromide revealed coupling of beta cells in both neonatal and adult islets (Fig. 7). The extent of LY diffusion did not change significantly with islet development, whereas that of ethidium bromide was greater $(p<0.01)$ in adult than in neonatal islets. Under these conditions, adult islets less frequently displayed uncoupled beta cells and more frequently $(p<0.01)$ displayed territories comprising at least seven coupled beta cells compared with neonatal islets (Fig. 7). Fetal and neonatal islets showed a similar coupling pattern (LY diffusion, neonatal $619.2 \pm 78.48 \mu \mathrm{m}^{2}[n=43]$, fetal $504.4 \pm 137.2 \mu \mathrm{m}^{2}[n=7]$; ethidium bromide diffusion, neonatal $847.1 \pm 42.6 \mu \mathrm{m}^{2}[n=34]$, fetal $842.0 \pm 131.0 \mu \mathrm{m}^{2}$ $[n=10])$.

\section{Discussion}

The ability to recognise increasing concentrations of glucose as a graded stimulus for acute insulin release is a unique and major characteristic of pancreatic beta cells. It has long been known that this glucose responsiveness is normally established in the few days that follow birth, even though beta cells are already equipped in the late prenatal period with most of their adult features [3-8]. Several events occurring during the early neonatal period, including changes in $\mathrm{K}^{+}$membrane permeability, production of GLUT2, protein kinase $\mathrm{C}$-alpha, $\mathrm{Ca}^{2+}$ channels and key enzymes of the NADH shuttles, are implicated in the maturation of beta cell function [1, 2, 4-8, 23-25]. We now show that gap junction/CX36 signalling, which contributes significantly to the proper function of adult beta cells [17, 
Fig. 2 CX36 production increases during development of rat pancreatic islets.

$\mathbf{a}-\mathbf{h}$ Confocal views of immunolabelled CX36 (green, a-d) and insulin (red, $\mathbf{e}-\mathbf{h})$ in fetal (a, e), neonatal $(\mathbf{b}, \mathbf{f})$, young $(\mathbf{c}, \mathbf{g})$ and adult $(\mathbf{d}, \mathbf{h})$ islets. The punctate CX36 distribution in beta cells is evident in young and adult islets, but much less in fetal and neonatal islets. Scale bar, $50 \mu \mathrm{m}$. i-k Sonicates of isolated islets (i) were immunoblotted for CX36 (j). The protein was mostly detected in its dimeric $(66 \mathrm{kDa})$ form $(\mathbf{j})$. $\mathbf{k}$ Densitometric evaluation revealed a marked postnatal increase in CX36 relative to all proteins stained by Ponceau $S$ (i). Values are mean + SEM of seven membranes from four independent experiments. M, molecular weight markers; $\mathrm{F}$, fetus; N, neonatal; Y, young; A, adult. ${ }^{*} p<0.05$ vs neonatal and fetal values
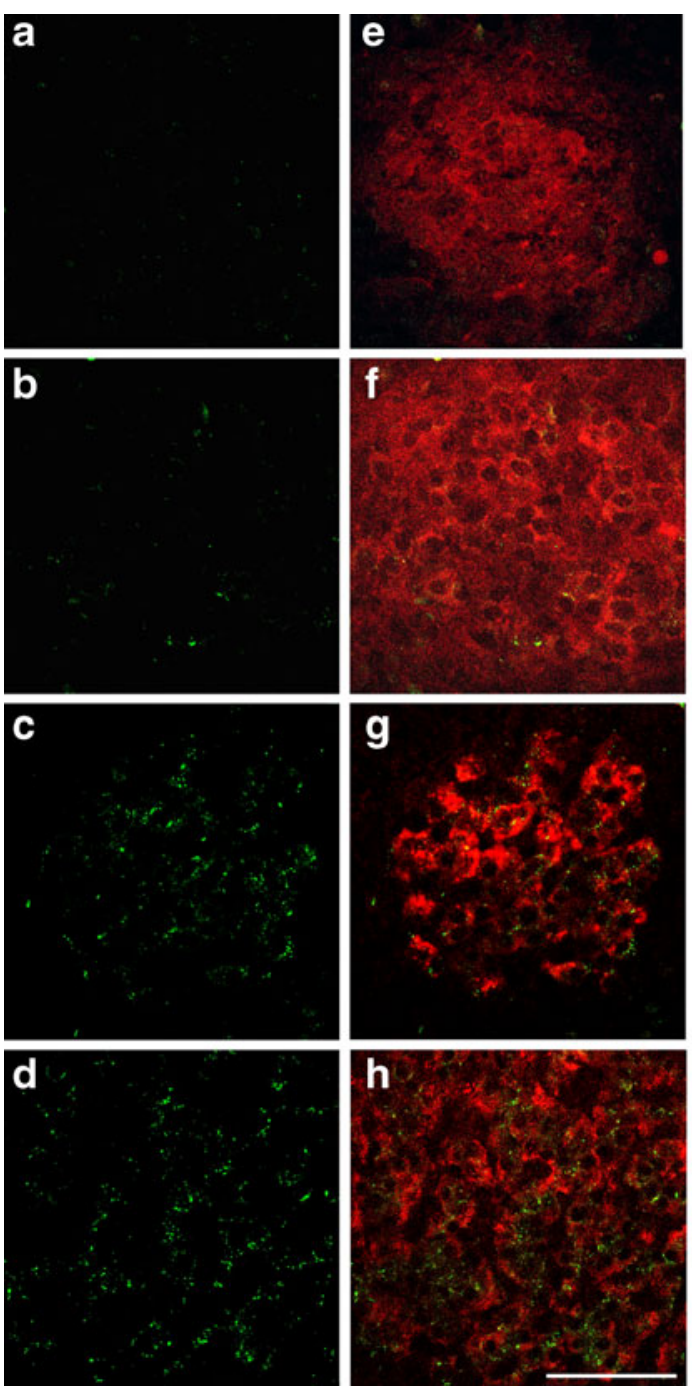

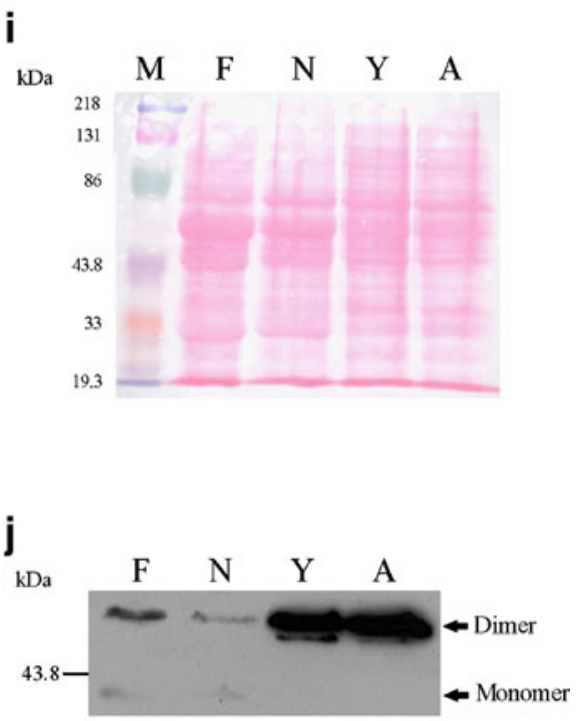

k

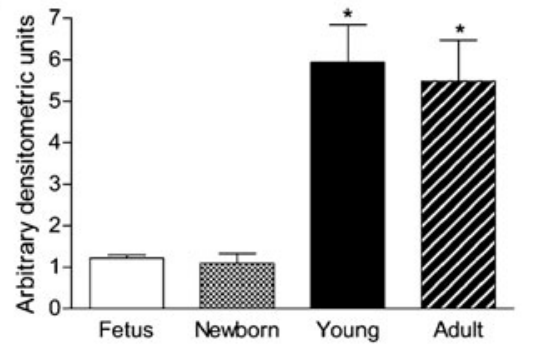

$18,26,27]$, is another key event in the final maturation of this function.

Here we provide the first evidence that structural and functional changes in gap junctions take place between beta cells in parallel with their developmental secretory maturation. Specifically, we have found that fetal and newborn rat beta cells express a similar pattern of gap junctions and coupling that is quite different from that observed in both young and adult animals. Thus, fetal and newborn beta cells, which respond poorly to glucose stimulation, produced little CX36, the native gap junction protein of adult beta cells $[18,22,28]$, and were modestly coupled to each other. These features changed after birth. Thus, glucoseresponsive young and adult rat islets featured increased levels of CX36 as a result of transcriptional activation of the cognate gene, and greater functional beta cell coupling, particularly when tested with positively charged tracers that preferentially permeate CX36 channels [22, 29].

Increasing evidence points to a requirement for adequate levels of CX36 and of the cell-to-cell channels this protein makes, to establish/retain appropriate insulin secretory in response to glucose stimulation [18-20]. Thus, loss of $C x 36$ results in increased basal insulin secretion and decreased or abolished glucose-stimulated insulin release in vitro and in vivo [17-20], as well as increased sensitivity of beta cells to conditions triggering apoptosis [30]. In vitro, most of these changes are also observed after pharmacological blockade of CX36 channels [15]. In vivo, beta cells lacking Cx36 also feature a delayed off response, i.e. they are slower than controls in turning off their insulin output when taken from a stimulatory to a basal condition [17]. The mechanisms involved in these changes are multifold, and may include the downregulation or loss of several CX36-dependent mechanisms, including the intercellular synchronisation of the glucose-induced $\mathrm{Ca}^{2+}$ transients [17, 19, 31], the intercellular transfer of electrotonic currents [32], the recruitment of intrinsically heterogeneous beta cells into secretory function [33], and the cross-talk with insulin regulatory pathways activated by ephrins [34]. Given that fetal and newborn beta cells feature defects in membrane 

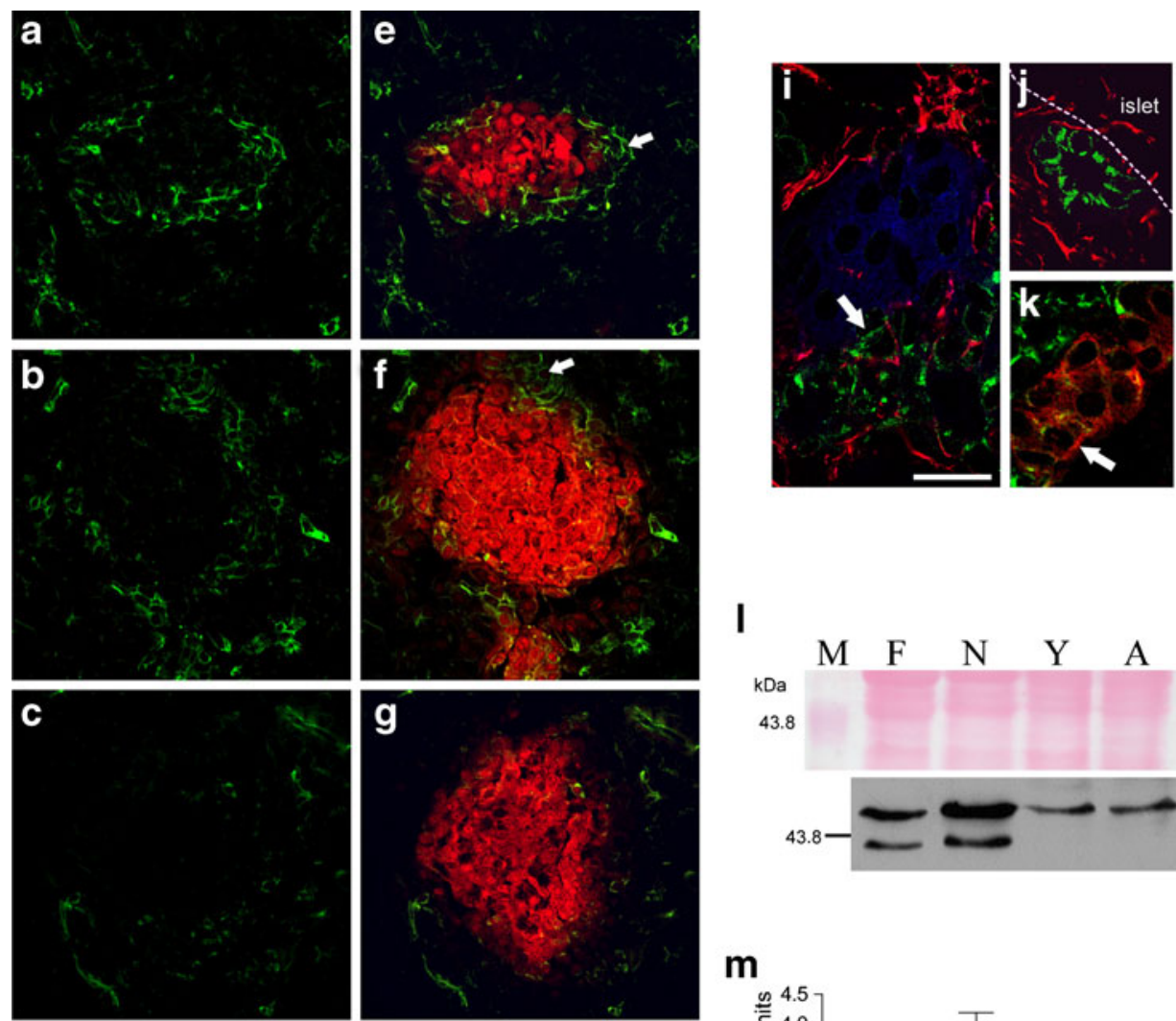

I
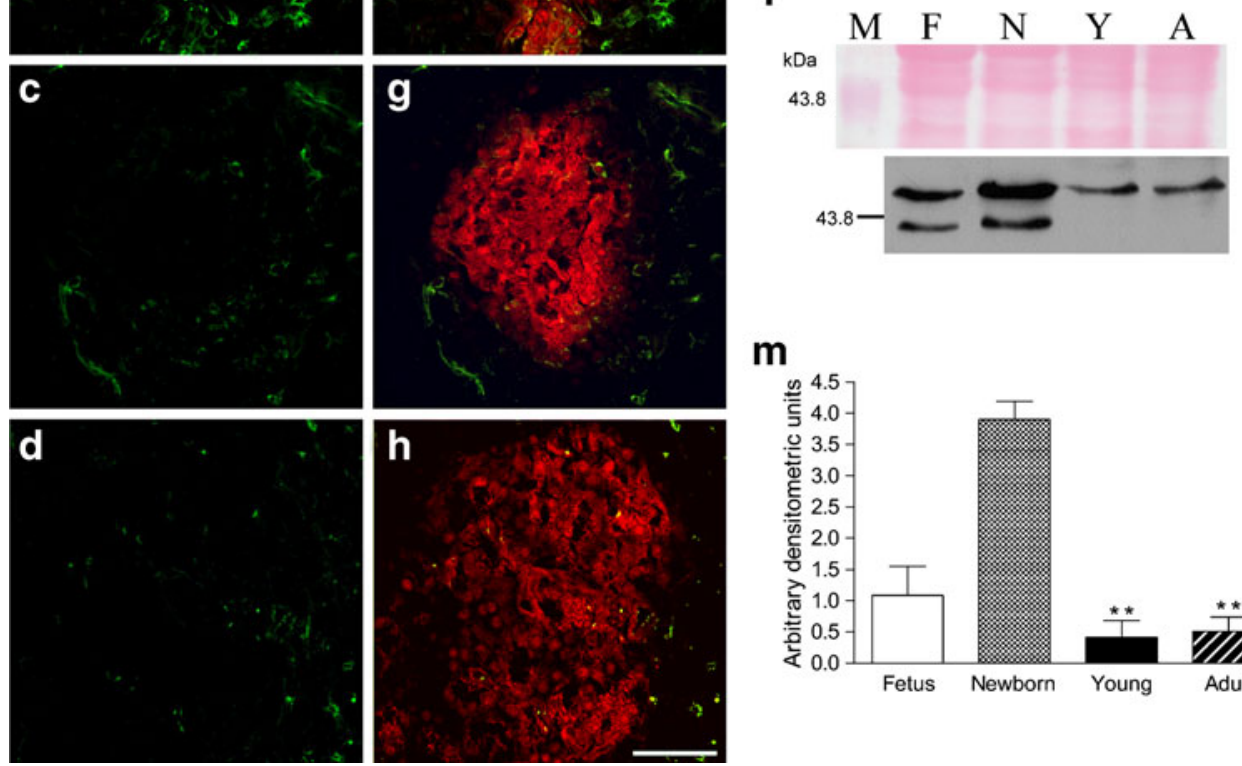

m

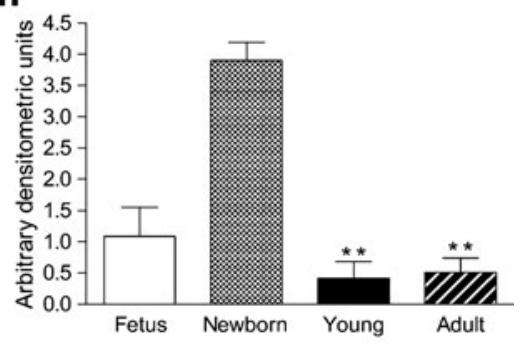

Fig. 3 Beta cells do not produce CX43 throughout the development of rat pancreatic islets. $\mathbf{a}-\mathbf{h}$ Confocal views of immunolabelled CX43 (green, a-d) and insulin (red, e-h) in fetal (a, e), neonatal $(\mathbf{b}, \mathbf{f})$, young $(\mathbf{c}, \mathbf{g})$ and adult islets $(\mathbf{d}, \mathbf{h})$. No CX43 was immunodetected in beta cells throughout islet development. In contrast, antibodies to CX43 immunostained some cells (arrows) at the periphery of fetal (a, e) and neonatal islets (b, f). i-k Triple labelling for CX43 (green), insulin (blue) and either vimentin (red in $\mathbf{i}, \mathbf{j}$ ) or glucagon (red in k) confirmed that the antibodies to CX43 did not stain beta cells (i), but appeared to stain vimentin-positive (i, arrow), duct (j, arrow) and alpha (k) cells at the periphery of a neonatal islet. Scale bars, $50 \mu \mathrm{m}$

depolarisation and $\mathrm{Ca}^{+2}$ handling $[1,2,4,7,8,24]$, it is conceivable that their modest expression of $\mathrm{Cx} 36$, gap junctions and beta cell coupling could account for their poor glucose-induced insulin secretion. Consistent with this view, we now show that a postnatal increase in the levels of the CX36 protein, the abundance of gap junctions and the extent of beta cell coupling accompanies the in vivo acquisition of glucose responsiveness, as previously suggested by preliminary in vitro experiments [9]. We further document that, during development, the levels of $C \times 36$ (a-h); $25 \mu \mathrm{m}(\mathbf{i}-\mathbf{k})$. I, m Islet sonicates (l) were immunoblotted for CX43. The protein was detected as two bands in fetal and neonatal islets, whereas the lower mobility form was detected in young and adult islets (I). m Densitometric evaluation revealed a marked postnatal decrease in CX43 relative to all proteins stained by Ponceau $\mathrm{S}$ (I). The difference in CX43 levels between fetal and neonatal islets did not reach statistical significance. Values are mean + SEM of five membranes from three independent experiments. $\mathrm{M}$, molecular weight markers; $\mathrm{F}$, fetus; $\mathrm{N}$, neonatal; Y, young; A, adult. ${ }^{* *} p<0.01$ vs neonatal value

expression correlate with those of the insulin gene, as recently reported in humans [29]. Beta cells of neonatal islets express significantly less insulin mRNA than those of adult rats [8], a difference that cannot be explained merely by developmental changes in beta cell number/volume [3]. Our data indicate that increased CX36 signalling may be required to achieve proper insulin expression, an essential landmark of beta cell maturation, a consideration which, in turn, raises the intriguing possibility that the CX36 and beta cell maturation events may not only be coincidental but 
Fig. 4 Transcription of $C x 36$ and $C x 43$ genes changed inversely during islet development. a, b Amplicons detected at different cycles in fetal, neonatal, young and adult islets, using primers for $C x 36$ (a) and $C x 43$ (b). c, d Quantitative evaluation of these amplicons showed that the levels of Cx36 mRNA increased with islet development, whereas those of $C x 43$ mRNA decreased in parallel. Data are mean+SEM normalised to the levels of Rps 29 mRNA for three independent experiments. $* * * p<0.001$ (c); ${ }^{*} p<0.05$ (d) vs fetal and neonatal values a
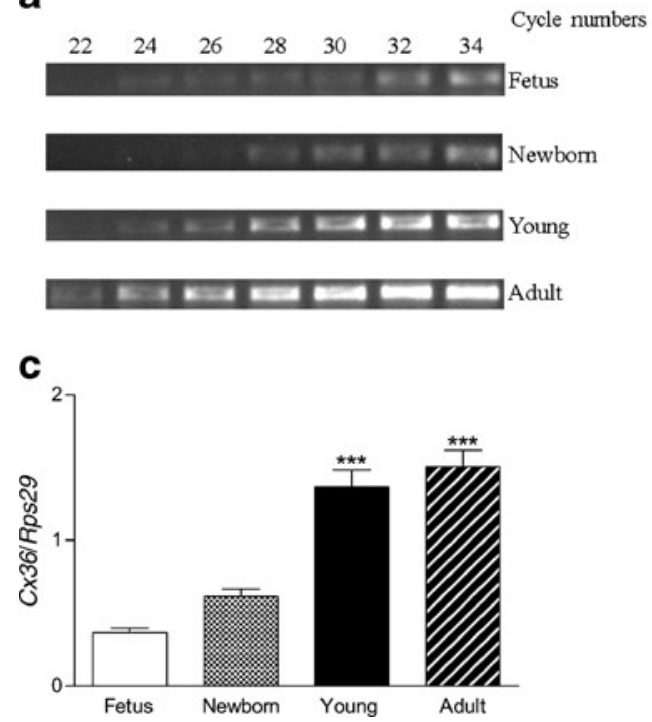

b
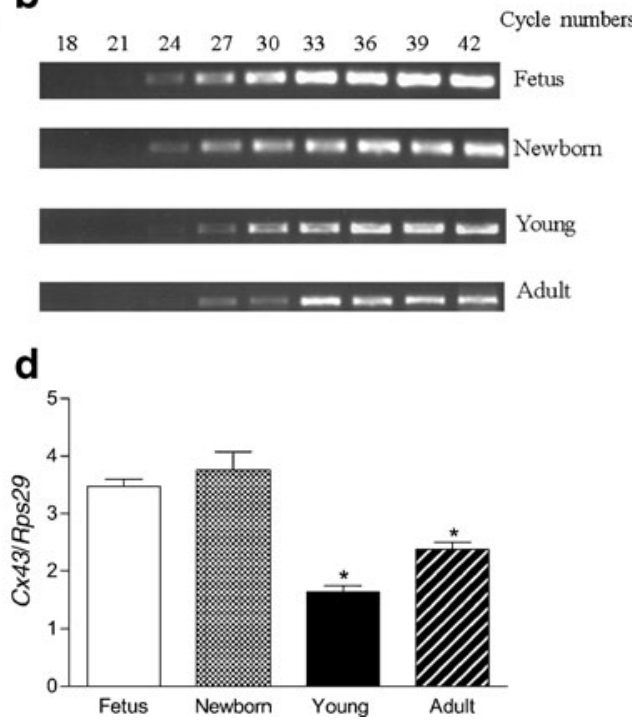

possibly also causally linked. Further experiments investigating the underlying molecular mechanism and/or mice featuring a beta cell-specific loss of CX36 [18] are now required to test this hypothesis.
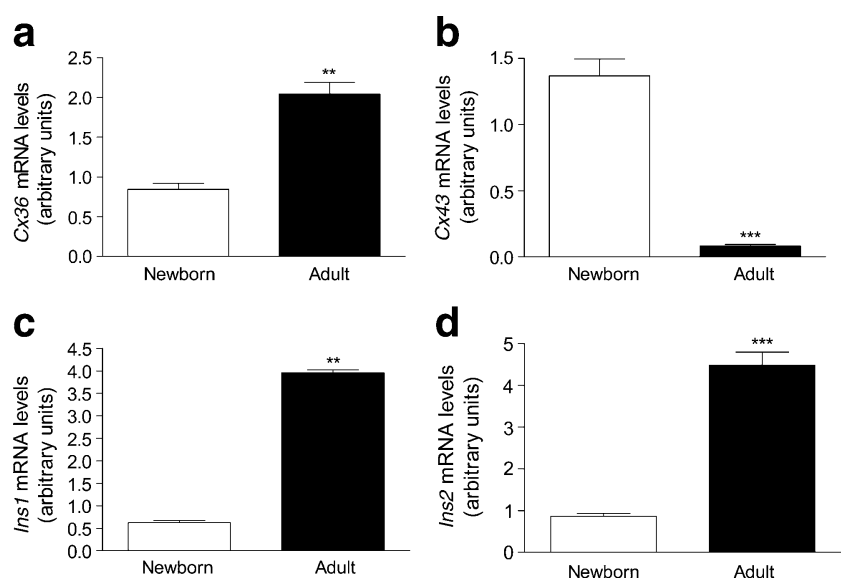

\section{d}
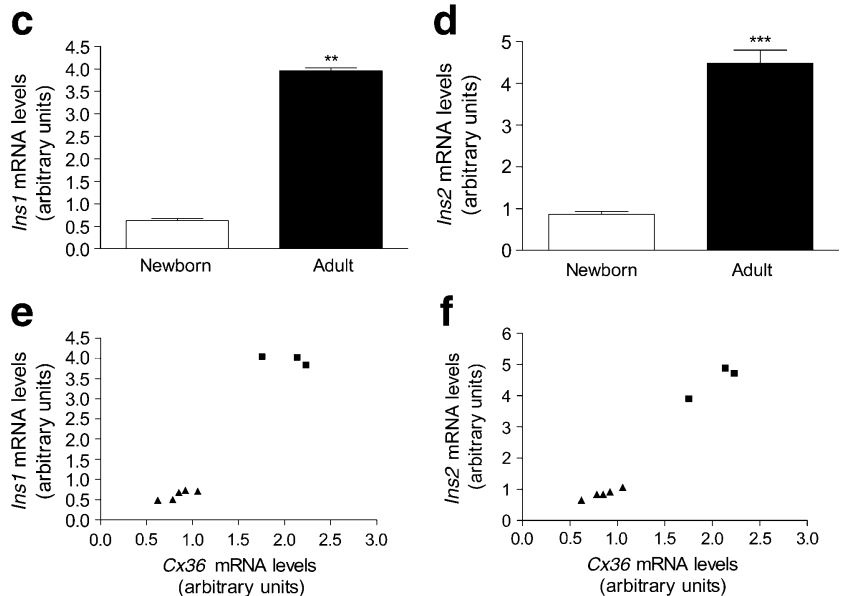

Fig. 5 Cx36 and insulin gene expression were correlated in neonatal and adult rat islets. a, b Quantitative PCR confirmed that the levels of Cx36 mRNA were higher in adult than neonatal islets, whereas those of $C x 43$ mRNA were lower. Data are mean + SEM normalised to the levels of Rps29, Gadph and Eeflal mRNAs for three independent experiments. e, $\mathbf{f}$ When related to the levels of mRNA expression of both the insulin 1 (Ins 1) and the insulin 2 (Ins2) gene, which also increased with islet development $(\mathbf{c}, \mathbf{d})$, a significant $(p<0.0001)$ correlation was found between the expression of $C \times 36$ and insulin mRNAs in neonatal (triangles) and adult (squares) islets. $* * * p<0.001$ vs neonatal value
Contrasting with most other cell types which coproduced several different connexin isoforms [35], adult beta cells produce only CX36 [18, 22, 28, 32, 36]. Still, the presence of different connexin transcripts, notably for CX43, has been reported repeatedly in the islets of different animal species [9, 14, 35, 37], presumably accounting for the connexin expressed by other cell types, including endothelial, connective and immune cells of islets [28]. Using available antibodies, we did not detect CX43 in the beta cells of all the islet groups we investigated and,

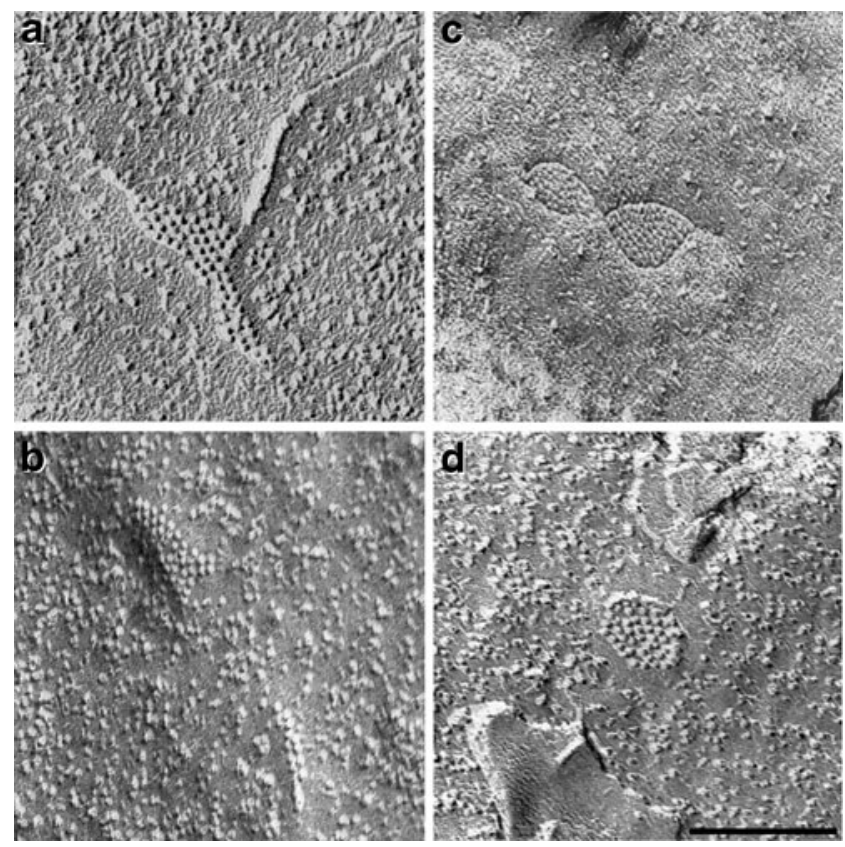

Fig. 6 Gap junctions connected beta cell membranes within neonatal and adult rat islets. Freeze-fracture electron microscopy revealed gap junction plaques in the beta cell membranes of both adult $(\mathbf{a}, \mathbf{b})$ and neonatal $(\mathbf{c}, \mathbf{d})$ islets. Gap junctions were often found associated with tight junction fibrils $(\mathbf{a}, \mathbf{c})$. Scale bar, $120 \mathrm{~nm}$ 
Table 1 Morphometric analysis of junctions in neonatal and adult rat pancreatic islets

\begin{tabular}{|c|c|c|c|c|c|c|c|}
\hline \multirow[t]{2}{*}{ Group } & \multirow{2}{*}{$\begin{array}{l}\text { No. of membranes } \\
\text { examined }\left(\mu \mathrm{m}^{2}\right)\end{array}$} & \multicolumn{2}{|c|}{ No. of membranes ${ }^{a}$} & \multicolumn{3}{|c|}{ Type of junction } & \multirow{2}{*}{$\begin{array}{l}\text { No. of gap junctions } \\
\text { per } 100 \mu \mathrm{m}^{2}\end{array}$} \\
\hline & & $\begin{array}{l}\text { With gap } \\
\text { junctions }\end{array}$ & $\begin{array}{l}\text { Without gap } \\
\text { junctions }\end{array}$ & $\begin{array}{l}\text { Gap } \\
\text { junction }\end{array}$ & $\begin{array}{l}\text { Gap + tight } \\
\text { junction }\end{array}$ & $\begin{array}{l}\text { Tight } \\
\text { junction }\end{array}$ & \\
\hline Newborn & $78(976)$ & 11 & 67 & $4(8.9 \%)$ & $22(48.9 \%)$ & $19(42.2 \%)$ & 2.66 \\
\hline Adult & $72(1000)$ & 30 & 42 & $23(13.8 \%)$ & $70(42.2 \%)$ & $73(44.0 \%)$ & 9.30 \\
\hline
\end{tabular}

Ten replicates from two independent pools of about 100 islets were analysed per group

${ }^{\mathrm{a}} p<0.0001$ for the distribution of junctions between neonatal and adult islets, as evaluated by the $\chi^{2}$ test

accordingly, we could not record a large intercellular exchange of Lucifer Yellow, a tracer that readily permeates CX43 channels [22, 38]. Rather, we observed with development an increase in beta cell coupling attributable to channels that were preferentially permeable to positively charged tracers, a signature of CX36 [22]. These data clearly demonstrate that maturing beta cells are functionally connected by CX36, but not CX43 channels, as reported in adult animals [18, 22, 28, 32, 36] and humans [29]. Still, antibodies to CX43 labelled vimentin-positive, duct and alpha cells at the periphery of newborn islets. The specificity of these immunostainings is presently supported by their loss with islet development, but should be fully validated after deletion of $C x 43$ in specific cell types, e.g. using the Cre-lox strategy $[18,28]$. Given that proliferating cells, some of which may be still undifferentiated progenitors of islet cells, are found at the periphery of fetal and neonatal islets [3, 39-41], and that CX43 is usually produced in undifferentiated stem and progenitor cells [42-44], further work should investigate whether these cells have any relevance for islet development or repair.

In summary, we have shown that the acquisition by rat islets of normal secretory function is tightly linked to selective changes in the production of gap junction proteins that result in increased assembly of gap junction plaques at beta cell membranes and in enhanced intercellular exchange of cationic molecules between cells of this type. As young islets reach full secretory maturation, their beta cells show CX36 coupling like that of adult beta cells. The close parallelism between these events and the close relationship between $C x 36$ and insulin levels raises the possibility that CX36 may be a useful target for inducing the maturation of beta cells in vitro [45], and for new approaches to the therapy of neonatal diabetes [46, 47].
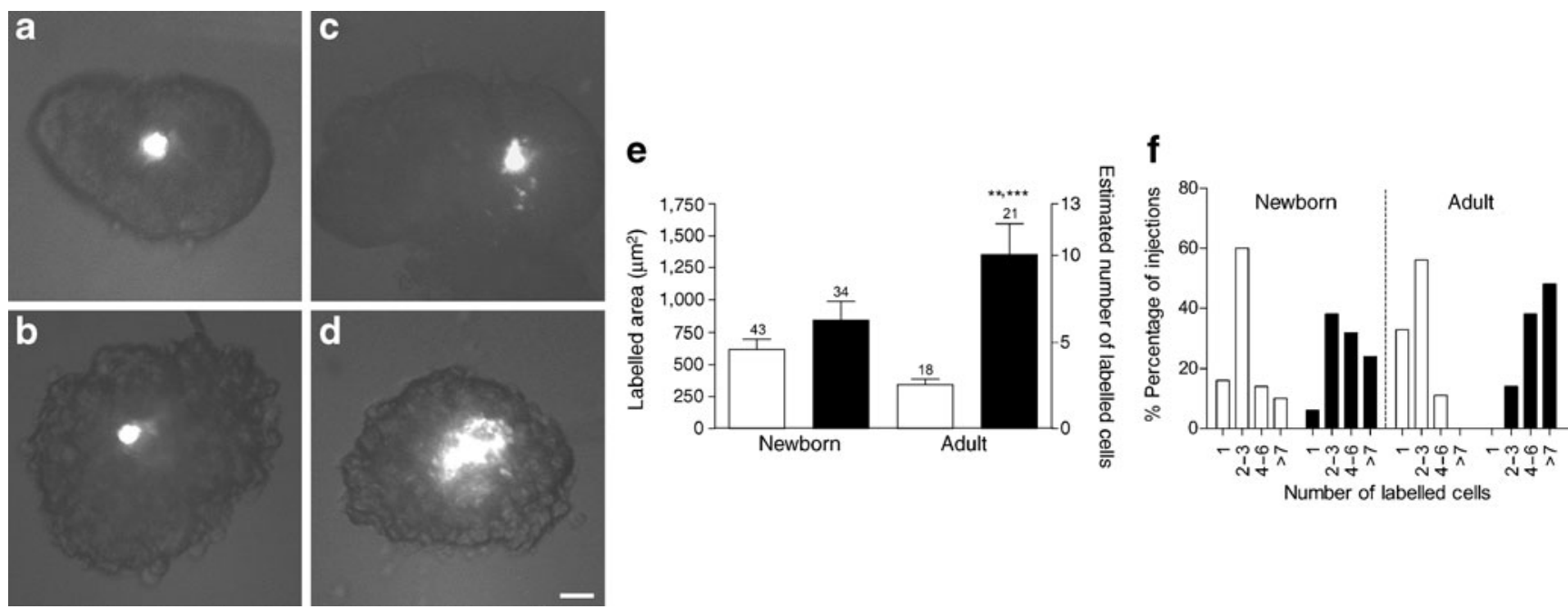

Fig. 7 Beta cell coupling changed with development of rat pancreatic islets. a-d Microinjection of neonatal (a, c) and adult intact islets (b, d) with either LY $(\mathbf{a}, \mathbf{b})$ or ethidium bromide $(\mathbf{c}, \mathbf{d})$ resulted in variable transfer of tracers into adjacent beta cells. In both islet types, the extent of ethidium bromide transfer was greater than that of LY, consistent with the presence of CX36 but not CX43 channels. Scale bar, $50 \mu \mathrm{m}$. e Quantitative analysis showed that whereas LY transfer (white bars) did not change significantly with islet development, the exchange of ethidium bromide (black bars) was greater $(p<0.01)$ in adult than neonatal islets. f Comparison of the coupling rank order between LY (white columns) and ethidium bromide (black columns), i.e. the number of beta cell diameters labelled by ethidium bromide, revealed that adult islets had fewer uncoupled cells (one cell) and more frequent territories comprising more than seven coupled beta cells than neonatal islets. Data in $\mathbf{e}$ are mean + SEM of the number of islets indicated above the columns. ${ }^{* *} p<0.01$ vs neonatal, LY; ${ }^{* * *} p<0.001$ vs adult, LY 
Acknowledgements The authors thank Marta Beatriz Leonardo, Léscio Domingos Teixeira (University of Campinas), Dorothée Caille, Anne Charollais, José Cancela and Pilar Ruga Fahy (University of Geneva) for excellent technical assistance. The authors thank Dr Hernandes F. Carvalho (University of Campinas) for the anti-vimentin and secondary antibodies. This work was funded by grants from FAPESP (99/06846-0, 02/11909-5, 02/13218-0, 06/50758-3) and CAPES/PROEX. C.P.F. Carvalho was a recipient of CAPES and $\mathrm{CNPq}$ fellowships (Brazil). C.B. Collares-Buzato was on sabbatical leave at the Department of Cell Physiology and Metabolism, University of Geneva, Switzerland, supported by CNPq (Brazil). The Meda team is supported by grants from the Swiss National Science Foundation (310000-109402), the Juvenile Diabetes Research Foundation International (1-2007-158) and the European Union (BETAIMAGE 222980, IMIDIA, C2008-T7).

Duality of interest The authors declare that there is no duality of interest associated with this manuscript.

\section{References}

1. Boschero AC, Tombaccini D, Atwater I (1988) Effects of glucose on insulin release and ${ }^{86} \mathrm{Rb}$ permeability in cultured neonatal and adult rat islets. FEBS Lett 236:375-379

2. Boschero AC, Crepaldi SC, Carneiro EM, Delattre E, Atwater I (1993) Prolactin induces maturation of glucose sensing mechanisms in cultured neonatal rat islets. Endocrinology 133:515-520

3. Carvalho CPF, Martins JCR, Cunha DA, Boschero AC, CollaresBuzato CB (2006) Histomorphology and ultrastructure of pancreatic islets during in vivo maturation of rat pancreas. Ann Anat 188:221-234

4. Weinhaus AJ, Poronnik P, Cook DI, Tuch BE (1995) Insulin secretagogues, but not glucose, stimulate an increase in $\left[\mathrm{Ca}^{2+}\right]_{\mathrm{i}}$ in the fetal rat beta-cell. Diabetes 44:118-124

5. Weinhaus AJ, Tabiin MT, Poronnik P, Palma CA, Cook DI, Tuch BE (2003) Insulin secretagogues, but not glucose, stimulate an increase in $\left[\mathrm{Ca}^{2+}\right] \mathrm{i}$ in the fetal human and porcine beta-cell. J Clin Endocrinol Metab 88:2753-2759

6. Mendonça AC, Carneiro EM, Bosqueiro JR, Crepaldi-Alves SC, Boschero AC (1998) Development of the insulin secretion mechanism in fetal and neonatal rat pancreatic beta cells: response to glucose, $\mathrm{K}^{+}$, theophylline, and carbamylcholine. Braz J Med Biol Res 31:841-846

7. Rozzo A, Meneghel-Rozzo T, Delakorda SL, Yang SB, Rupnik M (2009) Exocytosis of insulin: in vivo maturation of mouse endocrine pancreas. Ann N Y Acad Sci 1152:53-62

8. Navarro-Tableros V, Fiordelisio T, Hernández-Cruz A, Hiriart M (2007) Physiological development of insulin secretion, calcium channels, and GLUT2 expression of pancreatic rat $\beta$-cells. Am J Physiol Endocrinol Metab 292:E1018-E1029

9. Leite AR, Carvalho CPF, Furtado AG, Barbosa HCL, Boschero $\mathrm{AC}$, Collares-Buzato CB (2005) Co-expression and regulation of connexins 36 and 43 in cultured neonatal rat pancreatic islets. Can J Physiol Pharm 83:142-151

10. Amaral ME, Ueno M, Carvalheira JB et al (2003) Prolactin-signal transduction in neonatal rat pancreatic islets and interaction with insulin-signaling pathway. Horm Metab Res 35:282-289

11. Nielsen JH, Linde S, Welinder BS, Billestrup MOD (1989) Growth hormone is a growth factor for the differentiated pancreatic beta-cell. Mol Endocrinol 3:165-173

12. Halban PA, Wollheim CB, Blondel B, Meda P, Niesor EN, Mintz DH (1982) The possible importance of contact between pancreatic islet cells for the control of insulin release. Endocrinology 111:86-94
13. Bosco D, Orci L, Meda P (1989) Homologous but not heterologous contact increases the insulin secretion of individual pancreatic B cells. Exp Cell Biol 184:72-80

14. Meda P, Chanson M, Pepper MS et al (1991) In vivo modulation of connexin 43 gene expression and junctional coupling of pancreatic beta cells. Exp Cell Res 192:469-480

15. Meda P, Bosco D, Chanson M et al (1990) Rapid and reversible secretion changes during uncoupling of rat insulin-producing cells. J Clin Invest 86:759-768

16. Meda P, Perrelet A, Orci L (1979) Increase of gap junctions between pancreatic beta cells during stimulation of insulin secretion. J Cell Biol 82:441-448

17. Ravier MA, Güldenagel M, Charollais A et al (2005) Loss of connexin36 channels alters beta-cell coupling, islet synchronization of glucose-induced $\mathrm{Ca}^{2+}$ and insulin oscillations, and basal insulin release. Diabetes 54:1798-1807

18. Wellershaus K, Degen J, Deuchars J et al (2008) A new conditional mouse mutant reveals specific expression and functions of connexin 36 in neurons and pancreatic beta-cells. Exp Cell Res 314:997-1012

19. Calabrese A, Zang M, Serre-Beinier V et al (2003) Connexin 36 controls sychronization of $\mathrm{Ca}^{2+}$ oscillations and insulin secretion in MIN6 cells. Diabetes 52:417-424

20. Le Gurun S, Martin D, Formenton A et al (2003) Connexin-36 contributes to control function of insulin-producing cells. J Biol Chem 278:37690-37697

21. Meda P, Denef JF, Perrelet A, Orci L (1980) Nonrandom distribution of gap junctions between pancreatic beta-cells. Am J Physiol 238:C114-C119

22. Charpantier E, Cancela J, Meda P (2007) Beta cells preferentially exchange cationic molecules via connexin 36 gap junction channels. Diabetologia 50:2332-2341

23. Tan C, Tuch BE, Tu J, Brown SA (2002) Role of NADH shuttles in glucose-induced insulin secretion from fetal $\beta$-cells. Diabetes 51:2989-2996

24. Hole RL, Pian-Smith MCM, Sharp GWG (1988) Development of the biphasic response to glucose in fetal and neonatal rat pancreas. Am J Physiol 254:E167-E174

25. Fletcher DJ, Ways DK (1991) Age-dependent expression of protein kinase $C$ isoforms in rat islets. Diabetes 40:1496-1503

26. Rutter GA (2001) Nutrient-secretion coupling in the pancreatic islet beta-cell: recent advances. Mol Aspects Med 22:247-284

27. Klee P, Bavamian S, Charollais A et al (2008) Gap junctions and insulin secretion. In: Seino S, Bell GI (eds) Pancreatic beta cell in health and disease. Springer, Tokyo, pp 114-132

28. Theis M, Mas C, Döring B et al (2004) Replacement by a lacZ reporter gene assigns mouse connexin36, 45 and 43 to distinct cell types in pancreatic islets. Exp Cell Res 29:18-29

29. Serre-Beinier V, Bosco D, Zulianello L et al (2009) Cx36 makes channels coupling human pancreatic beta cells and correlates with insulin expression. Hum Mol Genet 18:428-439

30. Allagnat F, Klee P, Peyrou M et al (2007) The gap junctional protein Connexin36 (Cx36) protects pancreatic beta cells against cytotoxic attacks: a possible role in cytokine-mediated beta cell death. Diabetologia 50(Suppl 1):S45

31. Jonkers FC, Jonas JC, Gilon P, Henquin JC (1999) Influence of cell number on the characteristics and synchrony of $\mathrm{Ca}^{+2}$ oscillations in clusters of mouse pancreatic islet cells. J Physiol 520:839-849

32. Moreno AP, Berthoud VM, Pérez-Palacios G, Pérez-Armendariz EM (2005) Biophysical evidence that connexin-36 forms functional gap junction channels between pancreatic mouse beta-cells. Am J Physiol Endocrinol Metab 288:E948-E956

33. Salomon D, Meda P (1986) Heterogeneity and contact-dependent regulation of hormone secretion by individual B cells. Exp Cell Res 162:507-520 
34. Konstantinova I, Nikolova G, Ohara-Imaizumi M et al (2007) EphA-ephrin-A-mediated beta cell communication regulates insulin secretion from pancreatic islets. Cell 129:359-370

35. Meda P, Pepper MS, Traub O et al (1993) Differential expression of gap junction connexins in endocrine and exocrine glands. Endocrinology 133:2371-2378

36. Pérez-Armendariz M, Roy C, Spray DC, Bennett MV (1991) Biophysical properties of gap junctions between freshly dispersed pairs of mouse pancreatic beta cells. Biophys J 59:76-92

37. Vozzi C, Ullrich S, Charollais A, Philippe J, Orci L, Meda P (1995) Adequate connexin-mediated coupling is required for proper insulin production. J Cell Biol 131:1561-1572

38. Martinez AD, Hayrapetyan V, Moreno AP, Beyer EC (2002) Connexin43 and connexin45 form heteromeric gap junction channels in which individual components determine permeability and regulation. Circ Res 90:1100-1107

39. Bouwens L, Wang R-N, de Blay E, Pipeleers AG, Klöppel G (1994) Cytokeratins as markers of ductal cell differentiation and islet neogenesis in the neonatal rat pancreas. Diabetes 43:1279-1283

40. Conklin JL (1962) Cytogenesis of the human fetal pancreas. Am J Anat 111:181-193

41. Di Bella A, Regoli M, Nicoletti C, Ermini L, Fonzi L, Bertelli E (2009) An appraisal of intermediate filament expression in adult and developing pancreas: vimentin is expressed in alpha cells of rat and mouse embryos. J Histochem Cytochem 57:577-586

42. Dahl E, Winterhager E, Reuss B, Traub O, Butterweck A, Willecke K (1996) Expression of the gap junction proteins connexin 31 and connexin43 correlates with communication compartments in extraembryonic tissues and in the gastrulating mouse embryo, respectively. J Cell Sci 109:191-197

43. Todorova MG, Soria B, Quesada I (2008) Gap junctional intercellular communication is required to maintain embryonic stem cells in a non-differentiated and proliferative state. J Cell Physiol 214:354-362

44. Duval N, Gomès D, Calaora V, Calabrese A, Meda P, Bruzzone R (2002) Cell coupling and $\mathrm{Cx} 43$ expression in embryonic mouse neural progenitor cells. J Cell Sci 115:3241-3251

45. Santana A, Enseñat-Waser R, Arribas MI, Reig JA, Roche E (2006) Insulin-producing cells derived from stem cells: recent progress and future directions. J Cell Mol Med 10:866-883

46. Koster JC, Marshall BA, Ensor N, Corbett JA, Nichols CG (2000) Targeted overactivity of beta cell K(ATP) channels induces profound neonatal diabetes. Cell 100:645-654

47. Rocheleau JV, Remedi MS, Granada B et al (2006) Critical role of gap junction coupled KATP channel activity for regulated insulin secretion. PLoS Biol 4:221-227 